\title{
DETECTING KNEE CARTILAGE STRUCTURAL CHANGES USING MAGNETIC RESONANCE COMPUTED VISION ANALYSIS IN PATIENTS WITH OSTEOARTHRITIS: PRELIMINARY RESULTS
}

\author{
Ingus Supe ${ }^{1, \#}$, Artjoms Supoṇenkovs ${ }^{2}$, Ardis Platkājis ${ }^{1}$, Anda Kadiša ${ }^{3}$, \\ and Aivars Lejnieks ${ }^{3}$

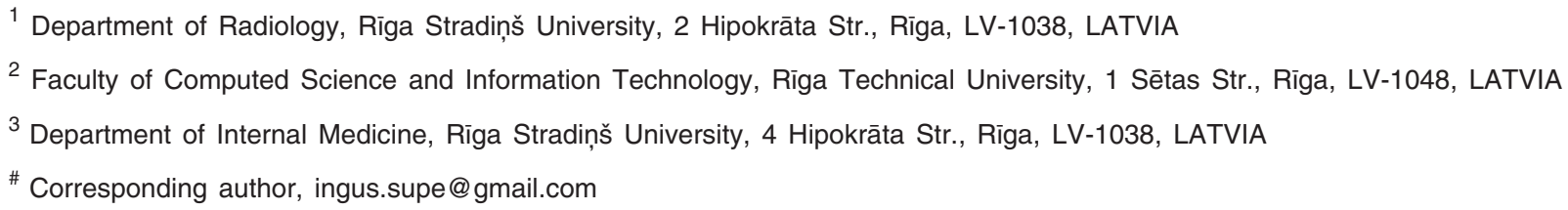

Contributed by Aivars Lejnieks

\begin{abstract}
Based on epidemiological data, osteoarthritis $(O A)$ is the most common joint disease of populations of industrialised countries. The increasing prevalence of $O A$ is closely related to an ageing population and a sedentary lifestyle. Load-bearing joints, such as hip, knee, and intervertebral joints, are the primary ones that are being subjected to the degenerative changes. The pathophysiology of the disease is based on progressive damage and gradual deterioration of the micro and macrostructure of hyaline cartilage. In today's radiological practice, the first-line method for assessing the condition of articular cartilage is magnetic resonance imaging (MRI). However, the sensitivity of standard clinical MRI in articular cartilage assessment is limited. For this reason, for the last five years there has been a rapidly growing interest in developing advanced MRI techniques for cartilage structure evaluation. The purpose of this pilot study was to highlight the possibilities of Artificial Intelligence Computed Vision Analysis (MEDH 3.0 algorithm) in the evaluation of cartilage changes of the knee joint. The study was carried out at Riga East Clinical University Hospital (RAKUS) and included 25 patients. After assessment by a rheumatologist, the participants were divided into two groups: 15 (60\%) participants with OA and $10(40 \%)$ healthy individuals. All patients underwent MRI examinations according to a unified RAKUS Gailezers Radiology clinic protocol. MRI data were analysed using the Computed Vision Analysis MEDH 3.0 algorithm. The results showed substantial differences in intensity variance $(\mathrm{p}<0.01)$ parameters, as well as in pixel entropy and homogeneity values $(\mathrm{p}<0.01)$. The results of the pilot study confirmed the potential use of Artificial Intelligence Computed Vision Analysis in further development and integration in the assessment of cartilage changes in the knee joint.
\end{abstract}

Key words: computed algorithm, knee joint, MRI, degenerative disease, articular cartilage.

\section{INTRODUCTION}

Osteoarthritis (OA) is the most common joint disease in the United States of America (USA) and Europe (Conaghan et al., 2014). According to the epidemiological data, prevalence of the disease in the population has a steadily increasing trend, which is closely associated with the growing rate of aging of the population and a sedentary lifestyle (Lawrence et al., 2008). Moreover, epidemiological projections suggest that in the coming decades, there will be a signifi- cant increase of OA incidence in populations of industrialised countries (Cross et al., 2014; Hunter et al., 2014).

Degeneration, together with thinning of articular cartilage layers, or chondromalacia, is the basis for development of $\mathrm{OA}$. OA is a chronic disease of joints that most commonly is associated with progressive, degenerative changes of an affected joint, resulting in diseases with typical symptoms such as chronic pain, stiffness, and limited mobility (Hunter et al., 2006; Crema et al., 2014). Gradual and slow chon- 
dromalacia is a normal aging process of a joint, but major weight-bearing joints, like hip, knee, or intervertebral joints, are subjected to increased risk for faster cartilage degeneration (Wick, 2012).

Unaltered, mature hyaline cartilage consists of a water fraction (65-85\% of its total mass), extracellular matrix (ECM) (15-25\%), and chondrocytes (4-5\%) (Maroudas et al, 1980). Normal water content, as well as its quantity within the ECM regions of the cartilage, provides cartilage with its specific biomechanical property — the ability to absorb tensile and compressive loads (Sophia et al, 2009).

ECM is composed of a type II collagen fibril network, to which are fixed proteoglycan (PG) molecules. PG consists of negatively charged glycosaminoglycans (GAGs) - disaccharide chains that are attached to a protein core. GAG contains negatively charged carboxyl and sulphate groups that interact with positively charged cations, such as sodium, which contributes to water retention in the cartilage structure (Binks et al., 2013). Cartilage type II collagen forms an isoelectric fibre network with integrated GAG chains (Venn et al., 1977).

The degenerative process of the articular cartilage starts with the loss of GAG, leading to an increase in free water content, followed by gradual collagen fibrillar network disorganisation and degradation. Before it is possible to qualitatively visualise changes in cartilage structure, such as fibrillation and partial-or full-thickness defects, oedema, or increase in water volume, an increase in MRI signal intensity can be seen in Proton Density (PD) and T2 weighted images (Quatman et al., 2011). Cartilage gradually loses its amortisation function, and as a result, progressive, irreversible changes or OA begin to develop in the joint (Buckwalter et al., 1998).

The imaging techniques used for radiological assessment of structural joint changes are conventional radiography (Xray) and magnetic resonance imaging (MRI). Despite the widespread use of conventional radiography in the diagnostics of musculoskeletal disorders (MSDs), the effectiveness of the method in detecting early joint degenerative changes using Kellgren-Lawrence OA classification is low (Kellgren and Lawrence, 1957). Five grades of Kellgren-Lawrence classification focus on joint space narrowing, osteophytes, endplate sclerosis, and erosions, which are non-direct features of cartilage damage.

In contrast, MRI with its excellent soft-tissue contrast differences in combination with multiplanar capabilities makes this radiological modality as the first-choice imaging method in assessing morphological and structural changes in cartilage (Peterfy et al., 2004; Ding et al., 2005). According to the European Society of Musculoskeletal Radiology (ESSR) guidelines, Proton Density (PD) and T2 weighted images with or without fat saturation (fs) are a standard procedure in the visualisation of knee joint cartilage. In daily MRI practice, the degree of chondromalacia is qualitatively evaluated using a semi-quantitative assessment system -
Outerbridge classification system, where the depth of the cartilage defect and the signal intensity alterations are evaluated (Outerbridge, 1961; Yulish et al., 1987). However, according to the literature, standard MRI sensitivity and specificity range in the diagnostics of the cartilage lesions from $50 \%$ for $1.5 \mathrm{MR}$ Tesla devices to $75 \%$ for 3.0 Tesla MR devices. In the last five years, in addition to standard MRI examination, there has been active research conducted on artificial intelligence-based MRI techniques. The method of perspective analysis of hyaline cartilage is MRI computed vision analysis. This method is based on the MR image textural feature analysis (Fu, 2011; Nansikova et al., 2011).

The aim of this pilot study is to highlight the possibilities of Artificial Intelligence - Computed Vision Analysis in the evaluation of cartilage changes of the knee joint in patients with osteoarthritis.

\section{MATERIALS AND METHODS}

Ethical approval for this study was received from the Ethics Committee of Medical and Biomedical Research of the Support Fund of the SIA "Riga East Clinical University Hospital" (protocol 10/19, 07.11.2019) permit No.16-A/19 and all study group participants signed an informed consent document.

The pilot study was conducted in the time period from 1 October 2019 to 1 March 2020. The study included 25 individuals: 15 patients $(60 \%)$ in the OA group and 10 practically healthy patients $(40 \%)$ in the control group. Of the 25 patients, 11 (44\%) were men and 14 (56\%) were women. The mean age in the OA group was $57.9+/-6.8$ years (40-69 years), and the mean age in the control group was $25.8+/-4.2$ years $(20-40$ years $)$.

The participants of the study were examined at the RAKUS radiological department using a GE General Electric SIGNA Architect 3.0T eight-channel knee joint coil magnetic resonance device. All examinations were done according to the same MR protocol: FSE PD fs ax, sag, cor, FSE PD 3D Cube and FSE T1 cor sequences. FSE PD 3D Cube parameters TE $32 \mathrm{~m} / \mathrm{s}$, TR $1502 \mathrm{~m} / \mathrm{s}$, SNR 100\%, pixel size $0.6 \times 0.6$, BW/Pixel 651 , echo spacing 5.5, slice thickness $1.0 \mathrm{~mm}$, frequency FOV 16.0, and phase FOV 1.0 .

The control group included healthy individuals up to 40 years of age without any clinical or radiological signs of OA or systemic inflammatory disease.

FSE PD 3D sagittal images (Fig. 1) were processed using HSV (Hue Saturation Value) and BGRA (Blue Green Red Alpha) colour models (Fig. 2) (Amira et al., 2016). After colour-coded processing, manual interactive segmentation of the hyaline cartilage was performed (Cuadra et al., 2020). The target tissues were segmented into sections at the level of the midline of medial and lateral condyles of the tibia and femur (Fig. 3). The following image textural fea- 


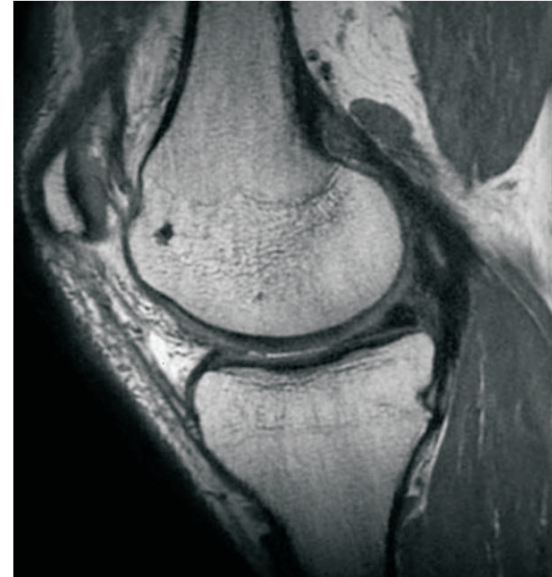

Fig. 1. MRI PD sagital 3D Cube image.

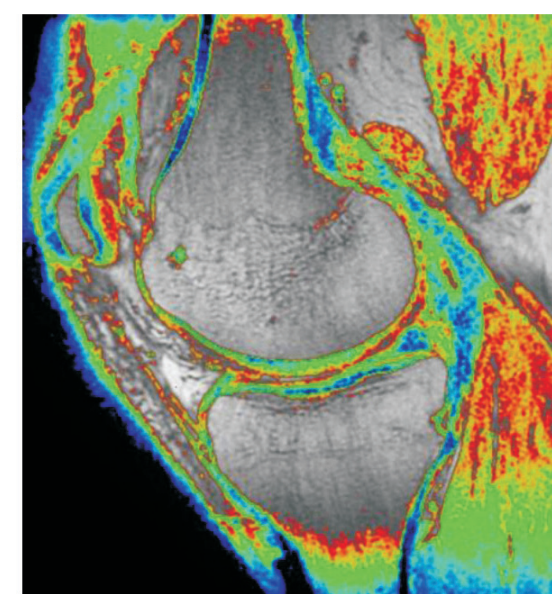

Fig. 2. MRI PD sagital 3D Cube image with BGRA Colour map.

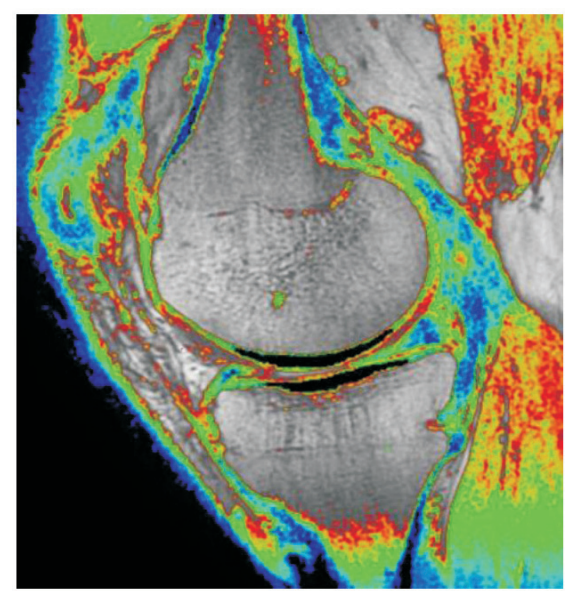

Fig. 3. MRI PD sagital 3D Cube image with BGRA Colour map and interactive segmentation. tures of the segments were analysed: mean signal intensity, signal intensity variance, entropy, and homogeneity.

The average segment signal intensity was calculated according to the formula (Zayed et al., 2015; Amri et al., 2019):

$\mu_{n}(x)=\sum_{i=0}^{L-1}\left(x_{i}-m\right)^{n} p\left(x_{i}\right)$

$x$ - value that reflects the brightness of the texture pixels;

$L$ - number of brightness levels;

$p(x)$ - the percentage of texture pixels with $\mathrm{x}$ brightness (number of pixels with $x$ brightness/number of texture pixels).

$\mu-1 \mathrm{D}$ central moment;

$m-$ mean value of texture brightness (mean).

Segmental pixel brightness variance was calculated using the following formula (Zayed et al., 2015; Amri et al., 2019): $\mu_{2}(x)=D(x)=\sigma^{2}(x)$. The variance represents pixel brightness deviation compared to values for mean brightness and brightness contrast.

The information about textural homogeneity and average entropy can help in the analysis of the segmental texture. The homogeneity index formula (Zayed et al., 2015; Amri et al., 2019) is:

$u(x)=\sum_{i=0}^{L-1} p^{2}\left(x_{i}\right)$.

As the value of $u(\mathrm{x})$ is closer to 1 the texture of the segment is more homogeneous.

The mean entropy or brightness variability index formula (Zayed et al., 2015; Amri et al., 2019) is:

$e(x)=\sum_{i=0}^{L-1} p\left(x_{i}\right) \log _{2} p\left(x_{i}\right)$.

As the entropy value is closer to 0 the segment texture is closer to spatially uniform brightness.

\section{RESULTS}

In the control group, the mean segmented area of lateral femoral and tibial condyle facets was $133 \mathrm{~mm}^{2}$ and for medial condyle facets $-108 \mathrm{~mm}^{2}$. In the OA group, the mean segmented area of lateral femoral and tibial condyle facets was $83 \mathrm{~mm}^{2}$ and for medial condyle facets $-53 \mathrm{~mm}^{2}$. For the control group, mean cartilage thickness at the lateral femur facet was $2.5 \mathrm{~mm}$, lateral tibia facet $3.3 \mathrm{~mm}$, medial femur facet 2.0, medial tibia facet $2.5 \mathrm{~mm}$. For the OA group, mean cartilage thickness at the lateral femur facet was 1.5 $\mathrm{mm}$, lateral tibia facet $2.5 \mathrm{~mm}$, medial femur facet 1.3 , and medial tibia facet $1.9 \mathrm{~mm}$.

The average signal intensity in the control group was 20.55 $+/-5.4$ and in the OA group $-23.02+/-4.89$ ( $p$ value 0.10 , $95 \%$ confidence interval from -5.48 to 0.55$)$. There was a statistically significant difference ( $p$ value $<0.01,95 \%$ confidence interval from -82.58 to -34.02$)$ in the pixel signal intensity variance between the control group $(10.62+/-$ 2.38) and the OA group (53.13+/-9.7) (Fig. 4).

Furthermore, the obtained results showed significant differences $(p$ value $<0.01)$ in entropy and homogeneity of the segments: entropy $(4.65+/-0.19)$ in the control group vs. $(5.17+/-0.26)$ in the OA group $(95 \%$ confidence interval from -0.66 to -0.38$)$ (Fig. 5); homogeneity $(0.047+/-$ $0.007)$ in the control group and $(0.032+/-0.0076)$ in the OA patient group (Fig. 6). According to data normality analysis, average signal intensity, signal intensity variance and segment entropy were evaluated using the unpaired $\mathrm{T}$ test and segment homogeneity values by the Mann-Whitney test.

Quantitative data were analysed using PRISM 8.4.0 software; the results are shown in boxplot diagrams.

\section{DISCUSSION}

There are several directions of MR image analysis related to $\mathrm{AI}$ in scientific databases, such as the Deep Machine Learn- 
Signal intensity variance

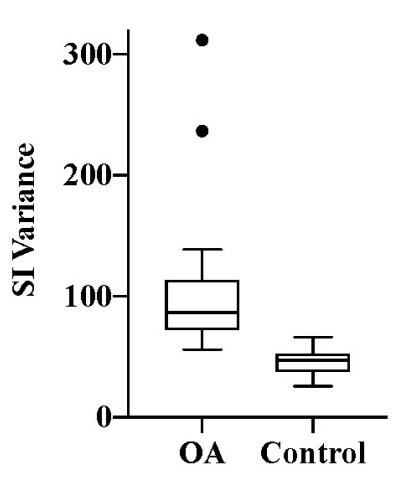

Fig. 4. Boxplots of signal intensity variance values.
Segment entrophy

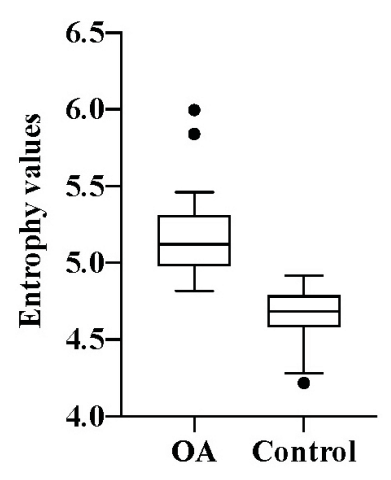

Fig. 5. Boxplots of segment entropy values.

\section{Segment homogenity}

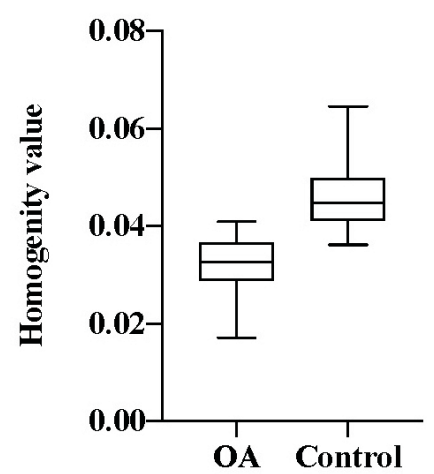

Fig. 5. Boxplots of segment homogeneity values. ing approach based on convolutional neural networks CNNs (Lui et al., 2018), and Multicomponent T2 analysis that focuses on the slow-relaxing water component, and fast relaxing water component $\mathrm{T} 2$ relaxation time analysis (Liu et al., 2016).

In order to evaluate changes in the structure of the knee joint articular cartilage, future studies should integrate additional patient data, such as gender, BMI and level of everyday physical activities. Furthermore, two independent radiologists should evaluate articular cartilage using Outbridge classification.

Further studies should choose a more balanced age group in the control and target groups, with a greater sample size in both groups.

In order to improve accuracy of segmentation and quality of data relevant to the intensity of the signal, the MRI examination protocol should be modified: the PD 3D sequence should be carried out in fat saturation mode. Semiautomatic and automatic cartilage segmentation function of the algorithm will be approbated during further research (Cuadra et al., 2020).

The widely used spin-spin T2 relaxation mapping technique can be used as an alternative method for cartilage quantification (Apprich et al., 2012).

In accordance with the good scientific practice, further stages of this research should use more targeted division of regions of interest in condylar cartilage. Such an approach will allow more accurate observation of degenerative changes in cartilage areas affected at a more early stage.

Successfully solving the above-mentioned issues would make it possible to use an artificial intelligence algorithm in the practice of musculoskeletal radiology.

\section{CONCLUSION}

This article represents the initial results and conclusions of a cooperation project between the Radiology and Internal Medicine Departments of Rīga Stradinšs University (RSU) and the Computed Science and Information Technology Faculty of Rīga Technical University (RTU). We developed this project in the context of an increasing number of scientific publications and studies that are related to the integration of various IT solutions in solving medical and diagnostic issues.

The results of this pilot study highlight the possibilities of the model of image textural features (MEDH 3.0. algorithm) in the quantitative assessment of cartilage, which in turn allows quantitative and objective analysis of the structural changes of hyaline cartilage. In this pilot study, four MR imaging textural features were selected: segment average signal intensity, signal intensity variance, segment entropy and homogeneity values. Despite the limited number of patients $(n=25)$, the last three MR imaging textural features presented statistically significant differences between the OA and control groups. The results show the perspectives of this research and correspond to the overall trend of growing artificial intelligence (AI) studies globally.

\section{REFERENCES}

Amira, B., R., Faouzi, B., Hamid, A. (2016). Segmentation of brain MRI using active contour model. Int. J. Imaging Syst. Technol., 27 (1), 3-11.

Apprich, S., Mamisch, T. C., Welsch, G. H., Stelzeneder, D., Albers, C., Totzke, J., Trattnig, S. (2012). Quantitative T2 mapping of the patella at 3.0 $\mathrm{T}$ is sensitive to early cartilage degeneration, but also to loading of the knee. Eur. J. Radiol., 81 (4), 438-443.

Armi, L., Fekri-Ershad, S. (2019). Texture image analysis and texture classification methods: A review. Int. Online J. Image Process. Pattern Recogn., 2 (1), 1-29.

Barr, C., Bauer, J. S., Malfair, D., Ma, B., Henning, T. D., Steinbach, L., Link, T. M. (2007). MR imaging of the ankle at 3 Tesla and 1.5 Tesla: Protocol optimization and application to cartilage, ligament and tendon pathology in cadaver specimens. Euro Radiol., 17 (6), 1518-1528.

Binks, D. A., Hodgson, R. J., Ries, M. E., Foster, R. J., Smye, S. W., Gonagle, D. Mc., Radjenovic, A. (2013). Quantitative parametric MRI of articular cartilage: A review of progress and open challenges. BRJ Radiology, 86 (1023), 120-163.

Buckwalter, J. A., Mankin, H. J. (1998). Articular cartilage: Degeneration and osteoarthritis, repair, regeneration, and transplantation. Instruction Course Lectures, 47 (1), 487-504. 
Conaghan, P. G., Kloppenburg, M., Schett, G., Bijlsma, J. W., EULAR osteoarthritis ad hoc committee (2014). Osteoarthritis research priorities: A report from a EULAR ad hoc expert committee. Ann. Rheum. Dis., 73 (8), 1442-1445.

Crema, M. D., Nevitt, M. C., Guermazi, A., Felson, D. T., Wang, K., Lynch, J. A., Marra, M. D., Torner, J., Lewis, C. E., Roemer, F. W. (2014). Progression of cartilage damage and meniscal pathology over 30 months is associated with an increase in radiographic tibiofemoral joint space narrowing in persons with knee OA the MOST study. Osteoarthr. Cartil., 22 (10), 1743-1747.

Cross, M., Smith, E., Hoy, D., Nolte S., Ackerman, I., Fransen, M., Bridgett, L., Williams, S., Guillemin, F., Hill, C. L. et al. (2014). The global burden of hip and knee osteoarthritis: Estimates from the Global Burden of Disease 2010 study. Ann. Rheum. Dis., 73 (7), 1323-1330.

Cuadra, M. B., Favre, J., Omoimi, P. (2020). Quantification in musculoskeletal imaging using compulational analysis and machine learning: Segmentation and radiomics. Semin. Musculoskel. Radiol., 24 (1), 50-64.

Ding, C., Garnero, P., Cicuttini. F., Scott, F., Cooley, H., Jones, G. (2005). Knee cartilage defects: Association with early radiographic osteoarthritis, decreased cartilage volume, increased joint surface area and type II collagen breakdown. Osteoarthr. Cartil., 13 (3), 198-205.

Fox, A. J. S., Bedi, A., Rodeo, S. A. (2009). The basic science of articular cartilage: structure, composition, and function. Sports Health, 1 (6), 461-468.

Hunter, D. J., Zhang, Y. Q., Tu, X., Lavalley, M., Niu, J. B., Amin, S., Guermazi, A., Genant, H., Gale, D., Felson, D. T. (2006). Change in joint space width: Hyaline articular cartilage loss or alteration in meniscus? Arthr. Rheum., 54 (8), 2488-2495.

Hunter, D. J., Schofield, D., Callander, E. (2014). The individual and socioeconomic impact of osteoarthritis. Nature Rev. Rheumatol., 10 (7), $437-441$

Kellgren, J. H., Lawrence, J. S. (1957). Radiological assessment of osteoarthrosis. Ann. Rheum. Dis., 16 (4), 494-502.

Lawrence, R. C., Felson, D. T., Helmick, C. G., Arnold, L. M., Choi, H., Deyo, R. A., Gabriel, S., Hirsch, R., Hochberg, M. C., Hunder, G. G., Jordan, J. M., Katz, J. N., Kremers, H. M., Wolfe, F., National Arthritis Data Workgroup (2008). Estimates of the prevalence of arthritis and other rheumatic conditions in the United States. Part II. Arthr. Rheum., 58 (1), 26-35.
Lidong, Fu., Zhang, B. (2011). A co-occurrence matrix algorithm used for medical image. In: Proceedings of International Conference on Computer Science and Network Technology, 24-26 December 2011, Harbin, China.

Liu, F., Choi, K., Samsonov, A., Spencer, R., Wilson, J., Block, W., Kijowski, R. (2016). Articular cartilage of the human knee joint: In vivo multicomponent T2 analysis 3.0 T. Radiology, 277 (2), 477-488.

Lui, F., Zhou, Z., Samsonov, A., Blankenbaker, D., Larison, W., Kanarek, A., Lian, K., Kambhampati, S., Kijowski, R. (2018). Deep learning approach for evaluating knee MR images: Achieving high diagnostic performance for cartilage leason detection. Radiology, 289 (1), 160-169.

Maroudas, A., Bayliss, M. T., Venn, M. F. (1980). Further studies on the composition of human femoral head cartilage. Ann. Rheum. Dis., 39 (5), 514-523.

Nasnikova, I. U., Morozov, S. P., Filisteev, P. A. (2011). Magnetic resonance tomography: Quantitative assessment methods in articular cartilage structure analysis of in patients with osteoartrosis. Russ. Electronic J. Radiol., 1 (1), 75-81.

Outerbridge, R. E. (1961). The etiology of chondromalacia patellae. J. Bone Joint Surg. Brit., 43 (B), 752-757.

Peterfy, C. G., Guermazi, A., Zaim, S., Tirman, P. F. J., Miaux, Y., White, D., Kothari, M., Lu, Y., Fye, K., Zhao, S., Genant, H. K. (2004). WholeOrgan Magnetic Resonance Imaging Score (WORMS) of the knee in osteoarthritis. Osteoarthr.Cartil., 12 (3), 177-190.

Quatman, C. E., Hettrich, C. M., Schmitt, L. C., Spindler, K. P. (2011). The clinical utility and diagnostic performance of magnetic resonance imaging for identification of early and advanced knee osteoarthritis: A systematic review. Amer. J. Sports Med., 39 (7), 1557-1568.

Venn, M., Maroudas, A. (1977). Chemical composition and swelling of normal and osteoarthrotic femoral head cartilage. Chemical composition. Ann. Rheum. Dis., 36 (2), 121-129.

Wick, M. C., Klauser, A. S. (2012). Radiological differential diagnosis of rheumatoid arthritis. Radiologe, 52 (2), 116-123 (in German).

Yulish, B. S., Montanez, J., Goodfellow, D. B., Bryan, P. J., Mulopulos, G. P., Modic, M. T. (1987). Chondromalacia patellae: Assessment with MR imaging. Radiology, 164 (3), 763-766

Zayed, N., Elnemr, H. (2015). Statistical analysis of Haralick texture features to discriminate lung abnormalities. Int. J. Biomed. Imaging, 2015, 267807, $1-7$.

\section{CELLA LOCĪTAVAS SKRIMŠL̨A STRUKTURĀLO IZMAIN̦U NOVĒRTĒŠANA, IZMANTOJOT MAGNĒTISKĀS REZONANSES DATORIZĒTA ALGORITMA ATTĒLU TEKSTŪRAS ANALĪZI OSTEOARTRĪTA PACIENTIEM: PILOTPĒTĪJUMA DATI}

Pēc epidemioloǵiskajiem datiem osteoartrīts $(\mathrm{OA})$ ir visbiežāk sastopamā locītavu saslimšana Amerikas Savienoto Valstu un Eiropas populācijās. OA augošā prevalence ir cieši saistāma ar sabiedrības novecošanos un mazkustīgu dzīvesveidu. Primāri deǵeneratīvām izmainām pakḷutas slodzi nesošās locìtavas, kā gūžu, ceḷu un intervertebrālās locītavas. OA saslimšanas patofizoloǵijas pamatā ir progresējošs skrimšḷa mikro un makrostrukturāls bojājums un pakāpeniska tā noārdīšanās. Šodienas radioloğiskā praksē kā pirmās rindas metode skrimšḷa stāvokḷa izvērtěšanai ir magnētiskā rezonanse (MR). Rutīnas MR ierobežotās jutības dēl, pēdējā piecgadē strauji augusi interese par advancētām MR tehnikām skrimšḷa kompozītstruktūras izvērtēšanā. Šì raksta mērkis ir iezīmēt datorizēta algoritma (MEDH 3.0 algoritms) iespējas ceḷa locītavas skrimšḷa izmaiņu izvērtēšanā. Pilotpētījumā tika iekḷauti 15 (60\%) pacienti OA grupā un 10 (40\%) veseli indivīdi kā kontroles grupa. Visiem pacientiem tika veikts MR izmeklējums pēc vienota protokola SIA RAKUS klīnikas Gail̨ezers Radioloǵijas nodaḷā. MR dati tika analizēti, izmantojot datorizēto MEDH 3.0 algoritmu. Rezultāti uzrādīja tendences vidējās signāla intensitātes vērtībās $(p=0,10)$, nozīmīgas atšķirības signāla intensitātes dispersijas rādītājos $(p<0,01)$, kā arī segmentu entropijas un homogenitātes rādītājos $(p<0,01)$. Pilotpētìjuma rezultāti iezīmē datorizētā algoritma attēlu teksturālo pazīmju modeḷa iespējas skrimšḷa kvantitatīvā novērtēšanā. 